\title{
Clinicopathological Characteristics and Differential Diagnosis of Signet-ring Cell Carcinoma of Gastric Pit Epithelium
}

\author{
Zhi-Shang Zhang \\ Shenzhen hospital of Southern medical University \\ Wei-Yi Deng \\ Shenzhen Southern Medical University \\ Si-Lin Huang \\ Shenzhen Hospital of Southern Medical University \\ Bin-Feng Yang \\ Shenzhen Hospital of Southern Medical University \\ Fang-Heng Zhu \\ Shenzhen Hospital of Southern Medical University

\section{Bo Jiang} \\ Shenzhen Hospital of Southern Medical University

\section{Su-Nan Wang} \\ Shenzhen Hospital of Southern Medical University \\ Yang-Kun Wang ( $\sim$ dr_wyk@163.com ) \\ Shenzhen Hospital of Southern Medical University
}

Research

Keywords: signet-ring cell carcinoma, gastric pit epithelial, signet ring-like atypical cells, histopathology, immunohistochemistry

Posted Date: December 21st, 2020

DOI: https://doi.org/10.21203/rs.3.rs-131104/v1

License: @ (i) This work is licensed under a Creative Commons Attribution 4.0 International License. Read Full License 


\section{Abstract}

Background:To investigate the clinicopathological characteristics, immunophenotype and differential diagnosis of signet-ring cell carcinoma of gastric pit epithelium.

Methods Seven cases of signet-ring cell carcinoma of gastric pit epithelium were studied by histomorphology observation, special staining, immunohistochemical staining and follow-up.

Results At the initial stage, the glands proliferated and expanded, and the cells morphologically transformed into signet ring-like atypical cells and then formed clonal hyperplastic signet-ring cell carcinoma, which expanded laterally along the gastric pit, with a length of 3-6 mm. Erosion or mucosal ulcers can be formed on the surface, and the atrophy of fundus or pylorus glands leads to local depression of gastric mucosa. PAS was positive by special staining. Immunophenotype testing included MUC5AC, CKpan, CK20, CEA, villin and CDX2 with positive expression. In cytology, five cell morphologies could be seen: classic, immature, high proliferation, non-nucleus vacuole and degeneration. Three out of seven cases were accompanied by Helicobacter pylori (Hp) infection, accounting for $42.9 \%$ of the cases.

Conclusion The signet-ring cell carcinoma of gastric pit epithelium originates from the proliferative region of the gastric fundus and the neck of gastric gland, which grows laterally along the gastric pit and is easy to be missed and misdiagnosed. Attention should be paid to the differential diagnosis, and the recognition level of signet-ring cell carcinoma of gastric pit epithelium should be improved.

\section{Background}

Signet-ring cell carcinoma is a special type of gastric adenocarcinoma that is highly malignant and often involves the full thickness of the stomach wall. The diagnosis rate of early signet-ring cell carcinoma is not high.[1-3] However, in recent years, studies have found that gastric and intestinal related immunophenotypes are related to biological behaviour and prognosis of signet-ring cell carcinoma.[4-6] According to the expression of markers, it is composed of gastric cancer and intestinal gastric cancer. The gastric cancer can be further divided into gastric pit epithelial (surface mucous epithelium), pyloric gland and fundus gland. Intestinal gastric cancer can be divided into absorption epithelial and goblet cell. [7-8] Signet-ring cell carcinoma is similar to intestinal gastric cancer, which originates from gastric mucosal epithelium.[9] Histologically, each gastric fundus is connected with three to five glands, which is the basic structural unit of gastric mucosa, called gastric units, and the structure is of monoclonal origin.[10] The gastric unit is composed of the gastric pit and gastric glands, and the gastric glands are composed of the isthmus, gland neck and basal part. The cells in the isthmus of the gastric gland and the upper part of gland neck proliferate actively, which is called the proliferation area. Studies have confirmed that the proliferating area is the origin of signet-ring cell carcinoma.[11] However, this area actually contains a variety of poorly differentiated cells with irregular structures. It is not clear what kind of cells in the proliferation area originated from signet-ring cell carcinoma.[12-13] Seven cases of signet-ring cell carcinoma were pathologically diagnosed. Endoscopic submucosal dissection (ESD) was performed in three cases and local excision in four cases. Five cases of histomorphology showed that the cells were transformed into signet-ring-like atypia. The signet-ring cell carcinoma formed clonal hyperplasia and expanded laterally along the gastric pit with a length of 3-6 mm. We diagnosed this tumour as signet-ring cell carcinoma of gastric pit epithelium. We then consulted the literature for reports similar to the gastric pit epithelium (surface mucous epithelium),[14-17] and there is still a lack of description of histomorphological characteristics. It is easy to misdiagnose and miss diagnosis of signet-ring cell carcinoma of gastric pit epithelium. We found that the aetiology of signet-ring cell carcinoma was related to the presence of $\mathrm{Hp}$ infection. In addition, the main points of histopathological diagnosis and differential diagnosis were put forward to improve the understanding level of signet-ring cell carcinoma of gastric pit epithelium.

\section{General Data And Methods}

1. General Data From January 2017 to December 2019, seven cases of patients with signet-ring cell carcinoma of the gastric mucosa diagnosed by gastroscopy biopsy were collected from the pathology department of Shenzhen Hospital of Southern Medical University, the pathology department of Xinxiang Central Hospital and the department of pathology of the 990th Hospital of the PLA Joint Logistic Support Force. Then, three cases underwent ESD resection, and four cases underwent local resection within 20-40 days. All specimens were fixed within 30 minutes after operation and then fixed with fresh $10 \%$ neutral buffered formalin solution (NBF) for 8-48 hours. The volume ratio of fixation solution to tissue was 10:1. According to the standardised sampling and preparation of gastric ESD specimens and premature gastric cancer specimens,[18-19] Hematoxylin-Eosin (HE) staining, special staining and immunohistochemical staining were performed, respectively.

2. Immunohistochemical Staining The tissue slice was deparaffinised, hydrated and rinsed with distilled water by EnVision two-step method. Then, the slice was placed in tris buffered saline (TBS) for 10 minutes. The endogenous peroxidase was blocked for five minutes, and the slice was treated with TBS for 10 minutes. Each primary antibody (CKpan, CK7, CK20, CEA, villin, CDX2, MUC1, MUC2, MUC5AC, MUC6, p53, ki-67, Hp) was incubated with the slice for 30 minutes at room temperature. After washing in TBS for 10 minutes, the slice was incubated in EnVisionTM. After washing in TBS for 10 minutes, the secondary antibody was applied for 10 minutes. The chromogenic substrate solution was incubated for 10 minutes and then washed with distilled water. DAB was used for colour development and haematoxylin was used for re-dyeing. The slice of gastric mucosa was used as a positive control, while the PBS buffer was used as the negative control instead of the first antibody. The working solutions were purchased from Shenzhen Dameng Biomedical Technology Co., Ltd., and the operation procedures were strictly in accordance with the instructions of the kit.

3. Follow-up The start time of the follow-up is the time the patient is discharged from the hospital after surgical treatment, and the follow-up ends in June 2020. The sample collection time is from December 2017 to December 2019, a total of 24 months. The follow-up time is 6 to 30 months. The follow-up method is by telephone or in-person visit.

\section{Results}


1. Clinical Data: The seven patients range in age from 26 years old to 51 years old, and the average age is 38.1 years old. The clinical manifestations are dull pain and discomfort in the upper abdomen, slight fullness, belching, acid reflux and other symptoms.

2. Clinicopathological Features: The tumour occurred in the gastric fundus in one case, the gastric body in three cases and the gastric antrum in three cases. The histopathological findings of ESD resection and local surgical resection showed that mucinous glands in the upper part of the gland neck were increased in five cases (Fig. 1a), accompanied by mild dilatation (Fig. 1b). Among the mucous neck cells, there were single or multiple signet-ring like cells. These cells are transformed from columnar cells. They are round in shape and larger in volume. The diameter is 1-2 times the peripheral columnar epithelium. The nucleus is crescent shaped. Cytologically, these are called signet-ring cell like atypia cells (Fig. 2a). These were initially located between normal mucous neck cells, and then gradually moved outside the gland (Fig. 2b). After differentiation and transformation, the cells formed independent monoclonal proliferation (Fig. 2c). Signet-ring cell carcinoma were formed, which were single or multiple, close to each other and selectively grew laterally in the gastric pit. Its growth pattern is slow, 'creeping' in the gastric pit area of the stromal spread, and it is basically friendly to the surrounding normal glands and is not invasive. There are inflammatory cells such as such as lymphocytes, plasma cells, neutrophils infiltrated in stroma, and lymphoid follicles formed in stroma. There is no proliferation of fibrous connective tissue, no cell for mucus, no intestinal metaplasia. The signet-ring cell carcinoma of the gastric pit showed transverse expansion in one-third of the opening side of the gastric fundus mucosa (Fig. 3a), and the length ranged from $3 \mathrm{~mm}$ to $6 \mathrm{~mm}$. Among the seven cases, three cases had gastric mucosal erosion or mucosal ulcer (Fig. 3b), and four cases had local mucosal depression caused by local mucosal thinning (Fig. 3c). There were three cases of $\mathrm{Hp}$ infection among the seven patients (Fig. 4a), accounting for $42.9 \%$ of the cases. Five types of cytological morphology were found in the signet-ring cell carcinoma of gastric pit epithelium: $\otimes$ Classic signet-ring cell, round in shape, $15 \mu \mathrm{m}-30 \mu \mathrm{m}$ in diameter, with light red stained mucus in the cytoplasm. The nuclei were deviated, with a signet-ring shape or crescent shape (Fig. 5a). $₫$ The immature signet-ring cells were round or irregular in shape, and the cytoplasm was strongly eosinophilic. The nucleus was irregular round, oval or deviated, and the ratio of nucleus to cytoplasm was 1:1-3. The chromatin of the nucleus was bichromatic (Fig. 5b). $\nabla$ Highly proliferative signet-ring cells were round or oval, with uniform cytoplasm and slightly stained with bichromatic mucus. The nuclei were large with prominent nucleoli, and the nuclei were deviated (Fig. $5 \mathrm{c}$ ). $\nabla$ The non-nucleus vacuole signet-ring cell, which is caused by the cut surface when making the slice, maintains the outline of the cytoplasm and the light red stained mucus in the cytoplasm (Fig. $5 \mathrm{~d}$ ). $\mathbb{Z}$ Degenerative signet-ring cells have larger cell volume, ranging from $20 \mu \mathrm{m}$ to $40 \mu \mathrm{m}$ and up to $50 \mu \mathrm{m}$, with capsule or incomplete capsule. The nucleus is small and lightly stained, and the nucleus is gray, or there is no nucleus (Fig. 5e).

3. Special Staining and Immunohistochemical Staining Results: Special staining PAS is purple-red (Fig. 6a). Immunohistochemical staining showed that MUC5AC (Fig. 6b), CKpan, CK20 (Fig. 6c), CEA, villin (Fig. 6d) and CDX2 were positive. MUC2 was positive in four cases (Fig. 6e) and negative in three cases. MUC1 was weakly positive in three cases and negative in four cases. The results of p53 were positive in two cases, weakly positive in three cases and negative in two cases. CK7 and MUC6 were negative. The number of ki-67 positive cells was 40-60\% (Fig. 6f), as shown in Table 1. 
Table 1

Clinicopathological characteristics and follow-up results of gastric fovea epithelial signet ring cell carcinoma

\begin{tabular}{|c|c|c|c|c|c|c|c|c|c|c|c|}
\hline Case & Age & Sex & position & $\begin{array}{l}\text { Pathological } \\
\text { diagnosis of } \\
\text { biopsy }\end{array}$ & $\begin{array}{l}\text { Early } \\
\text { cancer } \\
\text { treatment }\end{array}$ & $\begin{array}{l}\text { Histological } \\
\text { characteristics }\end{array}$ & $\begin{array}{l}\text { Special staining } \\
\text { and } \\
\text { immunophenotype }\end{array}$ & $\begin{array}{l}\text { pathologic } \\
\text { diagnosis }\end{array}$ & $\mathrm{Hp}$ & $\begin{array}{l}\text { Follow } \\
\text { up time } \\
\text { (months) }\end{array}$ & $\begin{array}{l}\text { Follow । } \\
\text { results }\end{array}$ \\
\hline 1 & 26 & $\mathrm{~F}$ & Gastric body & $\begin{array}{l}\text { Intramucosal } \\
\text { signet ring } \\
\text { cell } \\
\text { carcinoma }\end{array}$ & ESD & $\begin{array}{l}\text { The } \\
\text { proliferative } \\
\text { area grew } \\
\text { laterally with a } \\
\text { length of } \\
6 \mathrm{~mm} \text { and } \\
\text { mucosal } \\
\text { erosion. } \\
\text { Signet ring } \\
\text { like cells can } \\
\text { be seen }\end{array}$ & $\begin{array}{l}\text { PAS positive; } \\
\text { MUC5AC, ckpan, } \\
\text { CK20, CEA, villin, } \\
\text { CDX2, MUC2 were } \\
\text { positive; p53, } \\
\text { MUC1 were weakly } \\
\text { positive, CK7, } \\
\text { MUC6 were } \\
\text { negative, Ki67 } \\
\text { positive cells were } \\
60 \%\end{array}$ & $\begin{array}{l}\text { Signet } \\
\text { ring cell } \\
\text { carcinoma } \\
\text { of gastric } \\
\text { fovea }\end{array}$ & +++ & 28 & $\begin{array}{l}\text { No } \\
\text { recurrer }\end{array}$ \\
\hline 2 & 51 & $\mathrm{~F}$ & Gastric body & $\begin{array}{l}\text { Intramucosal } \\
\text { signet ring } \\
\text { cell } \\
\text { carcinoma }\end{array}$ & ESD & $\begin{array}{l}\text { The } \\
\text { proliferative } \\
\text { area was } \\
\text { expanded } \\
\text { laterally, the } \\
\text { length was } \\
4 \mathrm{~mm} \text {, and the } \\
\text { mucosa was } \\
\text { erosive. No } \\
\text { signet ring } \\
\text { shaped cells } \\
\text { were found }\end{array}$ & $\begin{array}{l}\text { PAS was positive; } \\
\text { MUC5AC, ckpan, } \\
\text { CK20, CEA, villin, } \\
\text { CDX2, p53 were } \\
\text { positive; MUC1 } \\
\text { was weakly } \\
\text { positive, CK7, } \\
\text { MUC2, MUC6 were } \\
\text { negative, Ki67 } \\
\text { positive cells were } \\
40 \%\end{array}$ & $\begin{array}{l}\text { Signet } \\
\text { ring cell } \\
\text { carcinoma } \\
\text { of gastric } \\
\text { fovea }\end{array}$ & positive & 30 & $\begin{array}{l}\text { No } \\
\text { recurrer }\end{array}$ \\
\hline 3 & 43 & $M$ & gastric antrum & $\begin{array}{l}\text { Intramucosal } \\
\text { signet ring } \\
\text { cell } \\
\text { carcinoma }\end{array}$ & $\begin{array}{l}\text { Local } \\
\text { excision }\end{array}$ & $\begin{array}{l}\text { The } \\
\text { proliferative } \\
\text { region is } \\
\text { transversely } \\
\text { expanded, } \\
\text { with a length } \\
\text { of } 3 \text { mm and } \\
\text { local } \\
\text { depression. } \\
\text { Signet ring } \\
\text { like cells can } \\
\text { be seen }\end{array}$ & $\begin{array}{l}\text { PAS positive; } \\
\text { MUC5AC, ckpan, } \\
\text { CK20, CEA, villin, } \\
\text { CDX2, MUC2 were } \\
\text { positive; p53 was } \\
\text { weakly positive; } \\
\text { CK7, MUC1, MUC6 } \\
\text { were negative, } \\
\text { Ki67 positive cells } \\
\text { were } 54 \%\end{array}$ & $\begin{array}{l}\text { Signet } \\
\text { ring cell } \\
\text { carcinoma } \\
\text { of gastric } \\
\text { fovea }\end{array}$ & +++ & 27 & $\begin{array}{l}\text { No } \\
\text { recurrer }\end{array}$ \\
\hline 4 & 39 & $M$ & gastric antrum & $\begin{array}{l}\text { Intramucosal } \\
\text { signet ring } \\
\text { cell } \\
\text { carcinoma }\end{array}$ & $\begin{array}{l}\text { Local } \\
\text { excision }\end{array}$ & $\begin{array}{l}\text { The } \\
\text { proliferative } \\
\text { region was } \\
\text { transversely } \\
\text { expanded, } \\
5 \mathrm{~mm} \text { in } \\
\text { length, and } \\
\text { partially } \\
\text { depressed. } \\
\text { Signet ring } \\
\text { like cells were } \\
\text { seen }\end{array}$ & $\begin{array}{l}\text { PAS was positive; } \\
\text { MUC5AC, ckpan, } \\
\text { CK20, CEA, villin, } \\
\text { CDX2, MUC2 were } \\
\text { positive; CK7, } \\
\text { MUC1, p53, MUC6 } \\
\text { were negative; } \\
\text { Ki67 positive cells } \\
\text { were } 37 \%\end{array}$ & $\begin{array}{l}\text { Signet } \\
\text { ring cell } \\
\text { carcinoma } \\
\text { of gastric } \\
\text { fovea }\end{array}$ & - & 14 & $\begin{array}{l}\text { No } \\
\text { recurrer }\end{array}$ \\
\hline 5 & 34 & $\mathrm{~F}$ & gastric varices & $\begin{array}{l}\text { Intramucosal } \\
\text { signet ring } \\
\text { cell } \\
\text { carcinoma }\end{array}$ & ESD & $\begin{array}{l}\text { The } \\
\text { proliferative } \\
\text { region was } \\
\text { transversely } \\
\text { expanded, } \\
\text { with a length } \\
\text { of } 6 \mathrm{~mm} \text { and } \\
\text { local } \\
\text { depression. } \\
\text { No signet ring } \\
\text { shaped cells } \\
\text { were found }\end{array}$ & $\begin{array}{l}\text { PAS was positive; } \\
\text { MUC5AC, ckpan, } \\
\text { CK20, CEA, villin, } \\
\text { CDX2 were } \\
\text { positive; CK7, p53, } \\
\text { MUC2, MUC1, } \\
\text { MUC6 were } \\
\text { negative; Ki67 } \\
\text { positive cells were } \\
57 \%\end{array}$ & $\begin{array}{l}\text { Signet } \\
\text { ring cell } \\
\text { carcinoma } \\
\text { of gastric } \\
\text { fovea }\end{array}$ & ++ & 11 & $\begin{array}{l}\text { No } \\
\text { recurrer }\end{array}$ \\
\hline 6 & 47 & $M$ & Gastric body & $\begin{array}{l}\text { Intramucosal } \\
\text { signet ring } \\
\text { cell } \\
\text { carcinoma }\end{array}$ & $\begin{array}{l}\text { Local } \\
\text { excision }\end{array}$ & $\begin{array}{l}\text { The } \\
\text { proliferative } \\
\text { region is } \\
\text { laterally } \\
\text { expanded, } \\
\text { with a length } \\
\text { of } 4 \mathrm{~mm} \text { and } \\
\text { a local } \\
\text { depression. } \\
\text { Signet ring } \\
\text { like cells can } \\
\text { be seen }\end{array}$ & $\begin{array}{l}\text { PAS was positive; } \\
\text { MUC5AC, ckpan, } \\
\text { CK20, CEA, villin, } \\
\text { CDX2, p53 were } \\
\text { positive; MUC1 } \\
\text { was weakly } \\
\text { positive, CK7, } \\
\text { MUC2, MUC6 were } \\
\text { negative, and Ki67 } \\
\text { positive cells were } \\
\text { 48\% }\end{array}$ & $\begin{array}{l}\text { Signet } \\
\text { ring cell } \\
\text { carcinoma } \\
\text { of gastric } \\
\text { fovea }\end{array}$ & - & 23 & $\begin{array}{l}\text { No } \\
\text { recurrer }\end{array}$ \\
\hline
\end{tabular}




\begin{tabular}{|c|c|c|c|c|c|c|c|c|c|c|c|}
\hline Case & Age & Sex & position & $\begin{array}{l}\text { Pathological } \\
\text { diagnosis of } \\
\text { biopsy }\end{array}$ & $\begin{array}{l}\text { Early } \\
\text { cancer } \\
\text { treatment }\end{array}$ & $\begin{array}{l}\text { Histological } \\
\text { characteristics }\end{array}$ & $\begin{array}{l}\text { Special staining } \\
\text { and } \\
\text { immunophenotype }\end{array}$ & $\begin{array}{l}\text { pathologic } \\
\text { diagnosis }\end{array}$ & $\mathrm{Hp}$ & $\begin{array}{l}\text { Follow } \\
\text { up time } \\
\text { (months) }\end{array}$ & $\begin{array}{l}\text { Follow } \\
\text { results }\end{array}$ \\
\hline 7 & 28 & $\mathrm{~F}$ & gastric antrum & $\begin{array}{l}\text { Intramucosal } \\
\text { signet ring } \\
\text { cell } \\
\text { carcinoma }\end{array}$ & $\begin{array}{l}\text { Local } \\
\text { excision }\end{array}$ & $\begin{array}{l}\text { The } \\
\text { proliferative } \\
\text { area was } \\
\text { transversely } \\
\text { expanded with } \\
\text { a length of } \\
5 \text { mm and } \\
\text { mucosal } \\
\text { erosion. } \\
\text { Signet ring } \\
\text { like cells can } \\
\text { be seen }\end{array}$ & $\begin{array}{l}\text { PAS was positive; } \\
\text { MUC5AC, ckpan, } \\
\text { CK20, CEA, villin, } \\
\text { CDX2, MUC2 were } \\
\text { positive; p53 was } \\
\text { weakly positive, } \\
\text { CK7, MUC1, MU'C6 } \\
\text { were negative; } \\
\text { Ki67 positive cells } \\
\text { were } 44 \%\end{array}$ & $\begin{array}{l}\text { Signet } \\
\text { ring cell } \\
\text { carcinoma } \\
\text { of gastric } \\
\text { fovea }\end{array}$ & ++ & 6 & $\begin{array}{l}\text { No } \\
\text { recurrer }\end{array}$ \\
\hline
\end{tabular}

4. Follow-up: The follow-up time was 6-30 months, no recurrence and metastasis.

\section{Discussion}

The early diagnosis rate of signet-ring cell carcinoma is not high. One important reason is that the pathological formation mechanism and the histomorphological characteristics of precancerous lesions of this type of gastric cancer are still unclear.[20-22] Studies have found that small lesions in lamina propria are difficult to diagnose by endoscopy, while early signet-ring cell carcinoma confined to submucosa has a higher incidence rate with larger volume. The incidence of lymph node metastasis of early signet-ring cell carcinoma is much lower than that of moderate and poorly differentiated adenocarcinoma. When signet-ring cell carcinoma invades the submucosa, tumour cells spread rapidly and widely.[23] We collected seven specimens of signet-ring cell carcinoma with small intramucosal lesions from three hospitals, which is consistent with reports in the literature. No lymph node metastasis or submucosal infiltration was found in the seven cases after ESD and local resection. No recurrence was found after 6-30 months of follow-up, especially in transverse growth. Therefore, it is called signet-ring cell carcinoma of gastric pit epithelium. Signet-ring cell carcinoma of gastric pit epithelium originated from the isthmus of the gastric gland and the proliferation area of the upper part of the neck gland. The differentiation characteristics: signet-ring cell like atypia cells could be seen in isthmus at the initial stage. At first, there were more glands in the neck area with slight expansion. There were signet-ring like cells between the mucous neck cells. The cells changed from columnar to round, and their volume increased. The diameter of the cells was 1-2 times that of the peripheral columnar epithelium. The nucleus was crescent shaped and formed the signet ring cell carcinoma on cytology. At first, it was still located in the gland, then it gradually moved out of the gland. Then, it was transformed, differentiated and proliferated to form independent monoclonal proliferation. The growth pattern and distribution characteristics of transformed clonal signet-ring carcinoma cells were mainly located in one-third of area of the opening side of the gastric fundus glandular mucosa, with transverse expansion and 'creeping' type of spread in the interstitium of the gastric pit. Because of the growth in and retention of the proliferative region, the growth and differentiation of normal gastric mucosa are prevented, resulting in the atrophy of glands in the lamina propria of gastric mucosa and the formation of local mucosal invagination. Six aspects of the diagnosis of signet-ring cell carcinoma of the gastric pit were proposed. (1) In the early stage, the glands in the gastric pit proliferated and expanded, and signet-ring atypia cells could be seen in most cases. (2) The cancer cells extended laterally along the gastric pit, with a length of 3-6 mm. (3) There were five morphologies in the process of cytological differentiation, which were classic signet-ring cell, immature signet-ring cell, highly proliferative signet ring cell, non-nucleus vacuole signet-ring cell and degenerative signetring cell. (4) More than half of the cases were accompanied with Hp infection. (5) Cancer cells located in the proliferative region prevented the normal differentiation of gastric glands, resulting in atrophy of lamina propria glands and formation of local mucosal invagination. (6) Special staining PAS was positive. The immunophenotype tests, MUC5AC, ckpan, CK20, CEA, villin and CDX2, were positive. For signet-ring cell carcinoma of gastric pit epithelium, the onset comes at a younger age, is more common in women, and is associated with $\mathrm{Hp}$ infection. More than half of the world's population is infected with $\mathrm{Hp}$, and most of them are asymptomatic. About 10\% of the population develop peptic ulcers, atrophic gastritis, gastric cancer and MALT lymphoma.[24-27] More and more evidence shows that $\mathrm{Hp}$ strain, the host, the presence of cyclobacteria and other factors jointly determine the occurrence and development of the disease.[28] As an important part of the micro-ecological environment in the stomach, gastric flora maintain the balance of the gastric environment through a variety of regulatory pathways. Once the bacterial community structure changes, this balance is bound to be broken, which will lead to disease.[29] The World Health Organization has classified $H p$ infection as a carcinogen of gastric cancer, and it has become a trend to eliminate $H p$ bacteria and prevent gastric cancer through detection and treatment of $\mathrm{Hp}$ bacteria.[30] This study found that three out of seven cases of signet-ring cell carcinoma of gastric pit epithelium were accompanied by $H p$ infection, accounting for $42.9 \%$, suggesting that $H p$ is an important factor leading to signet-ring cell carcinoma of gastric pit epithelium. Because $H p$ adheres to and selectively destroys the cytoplasm of the surface mucous cells, the cytoplasm is swollen and vacuolated, and the degenerated epithelial cells fall off in pieces, leading to gastric mucosal erosion or ulcers.[31] In cases of $\mathrm{Hp}$ infection in signet-ring cell carcinoma of gastric pit epithelium, a large number of $H p$ bacteria are located in the neck of the gland, and the signet-ring cell carcinoma of gastric pit epithelium originating from the same site as $H p$ infection. Whether or not $H p$ infection can directly lead to the spread and transformation of the cells in the proliferating area and lead to the occurrence of signet-ring cell carcinoma of gastric pit epithelium, its evolutionary process and mechanism for growth need to be further studied.

Another important factor in the low early diagnosis rate of gastric signet-ring cell carcinoma is that it is easy to be missed and misdiagnosed. Especially the differentiation stage of signet-ring cell carcinoma of gastric pit epithelium is not being detected early enough. We propose the following differential diagnosis: (1) Gastric xanthoma: Gastric xanthoma is benign and is mainly caused by lipid deposition. It is named because of its yellow colour. The pathogenesis of gastric xanthoma is still unclear, which may be related to diet and long-term inflammatory stimulation of gastric mucosa. Some scholars believe that chronic inflammation causes focal destruction of gastric mucosa, and residual lipid debris is absorbed by macrophages and then aggregates into a foam cell nest structure.[32] Histologically, the cell boundaries of macrophages in the gastric lamina propria are clear. The macrophages are round or polygonal. The cytoplasm is rich and foamy, and the nucleus is small and round, located in the centre of the cell. Immunophenotype testing of xanthoma cells (foam cells) show CD68 and MUC5AC are negative. (2) Ectopic fat deposition: Ectopic fat deposition refers to excessive accumulation of lipids in non-adipose tissue, 
mainly triglycerides, often in the liver, muscle, pancreas, gastric mucosa and other areas of the body. Studies have shown that ectopic fat deposition is closely related to the occurrence and development of metabolic diseases, but its mechanism has not been fully elucidated. Chronic inflammatory response can increase the expression of adipogenesis genes SREBP-1, ACC aand Fas in non-adipose tissue and adipolysis genes ATGL and HSL in adipose tissue. This promotes lipid synthesis, increasing adipolysis, reducing fat storage capacity of adipose tissue, and eventually leading to ectopic fat deposition.[33] Histologically, the mature adipocytes were distributed in the interstitium of gastric mucosa. The vacuoles were clear, and there was no mucus in the cytoplasm. Immunophenotype testing showed that S100 was expressed, and MUC5AC was negative. (3) Degeneration of gastric pit epithelium: Stem cells proliferating in normal gastric mucosa can migrate upwards and differentiate into surface mucous cells. Some stay local or migrate downwards and differentiate into other gastric fundus gland cells, and the life span of mucus neck cells is about one week.[34] Under the general situation of pathology, there will be a large amount of shedding, and signet-ring like cells will be formed when the degeneration is carried out. This kind of cell was only located on the surface of gastric mucosa, and there was no proliferation area of the gastric mucosa. The morphology of the cells was not heteromorphic, and there was no classical signet-ring cell carcinoma. Immunophenotype testing showed that ki67 was not expressed. (4) Mixed signet-ring cell carcinoma: The early mixed signet-ring cell carcinoma and the signet-ring cell carcinoma of gastric pit epithelium are mainly morphologically differentiated. The signet-ring cell carcinoma of the former is usually less than $50 \%$. It mainly contains non signet-ring cell carcinoma, including undifferentiated cancer, poorly differentiated adenocarcinoma, etc. (5) Primary/metastatic epithelioid malignant melanoma of the stomach: Histologically, the tumour tissue forms an embedded glandular and solid nest-like structure, arranged in a manner similar to the glands in the lamina propria, with few fibrous tissue intervals and less inflammatory cell infiltration. Cytologically, the tumour cells were rich in cytoplasm and basophilic, and there were different amounts of melanin granules in the cytoplasm. The nuclei were irregular round, slightly to moderately heteromorphic, with fine chromatin and large eosinophilic nucleoli. The tumour tissue infiltrated and formed massive necrosis, and brown pigment granules could still be seen in the necrotic foci. Mitotic images were 1-3/HPF. Immunophenotype testing showed that HMB45, MART-1 and S100 were expressed, while MUC5AC, CK20, villin and MUC2 were not expressed.

In conclusion, through the analysis of seven cases of early signet-ring cell carcinoma, we proposed the location and early differentiation characteristics, growth mode and distribution, morphological characteristics of five signet-ring cell carcinomas, immunophenotype, histopathological diagnosis and differential diagnosis of signet-ring cell carcinoma of gastric pit epithelium. It was also found that $H p$ infection was found in three of the seven patients with signet-ring cell carcinoma of gastric pit epithelium, accounting for $42.9 \%$, suggesting that $\mathrm{Hp}$ is an important factor leading to signet-ring cell carcinoma of gastric pit epithelium. It is of great significance to study the occurrence and mechanism of signet-ring cell carcinoma, control the incidence of signet-ring cell carcinoma of gastric pit epithelium, and guide clinical early treatment.

\section{Abbreviations}

Hp: Helicobacter pylori

NBF: neutral buffered formalin solution

HE: Hematoxylin-Eosin

TBS: tris buffered saline

\section{Declarations}

\section{Ethics approval and consent to participate}

This study was conducted in accordance with the Declaration of Helsinki and approved by the ethics committee of Shenzhen Hospital of Southern Medical University.

\section{Consent for publication}

Not applicable.

\section{Availability of data and materials}

All data generated or analyzed during this study are included in this published article

\section{Competing interests}

All of the authors had no any personal, financial, commercial, or academic conflicts of interest separately.

\section{Funding}

Henan Province key science and technology research plan project (132102310008)

\section{Authors' contributions}

WYK, ZZS and DWY conceived of the study, and HSL participated in its design and coordination and YBF, ZFH, JB and WSN helped to draft the manuscript. All authors read and approved the final manuscript. 
Not applicable

\section{References}

[1] Simon Pernot, Thibault Voron, Geraldine Perkins, Christine Lagorce-Pages, Anne Berger, Julien Taieb.Signet-ring cell carcinoma of the stomach: Impact on prognosis and specific therapeutic challenge. World J Gastroenterol. 2015 Oct 28;21(40):11428-38.

[2] Chon HJ, Hyung WJ, Kim C, Park S, Kim JH, Park CH, Ahn JB, Kim H, Chung HC, Rha SY, Noh SH, Jeung HC.Differential Prognostic Implications of Gastric Signet Ring Cell Carcinoma: Stage Adjusted Analysis From a Single High-volume Center in Asia. Ann Surg. 2017 May;265(5):946-953.

[3] Nichetti F, Morano F, Fabbri A, de Braud F, Di Bartolomeo M.Bilateral parotid gland metastases from gastric signet-ring cell carcinoma. Tumori. 2018 Dec;104(6):NP10-NP13.

[4] P S Akabah, S Mocan, C Molnar, D Dobru .Importance of optical diagnosis in early gastric cancer: A case report of early gastric signet ring cell carcinoma.Niger J Clin Pract. 2017 Oct;20(10):1342-1345.

[5] Kushima R, Vieth M, Borchard F, Stolte M, Mukaisho K, Hattori T.Gastric-type well-differentiated adenocarcinoma and pyloric gland adenoma of the stomach. Gastric Cancer. 2006;9(3):177-84.

[6] Goldstein NS, Long A, Kuan SF, Hart J.Colon signet ring cell adenocarcinoma: immunohistochemical characterization and comparison with gastric and typical colon adenocarcinomas. Appl Immunohistochem Mol Morphol. 2000 Sep;8(3):183-8.

[7] Yuasa Y.Control of gut differentiation and intestinal-type gastric carcinogenesis. Nat Rev Cancer. 2003 Aug;3(8):592-600.

[8] Odze RD, Lam AK, Ochiai A and Washington MK: WHO classification of tumours of the digestive system. Lyon: International Agency for Research on Cancer, 2019.

[9] Benedict MA, Lauwers GY, Jain D.Gastric Adenocarcinoma of the Fundic Gland Type: Update and Literature Review. Am J Clin Pathol. 2018 Apr 25;149(6):461-473.

[10] Tadashi Terada.An immunohistochemical study of primary signet-ring cell carcinoma of the stomach and colorectum: II. Expression of MUC1, MUC2, MUC5AC, and MUC6 in normal mucosa and in 42 cases. Int J Clin Exp Pathol. 2013;6(4):613-21. Epub 2013 Mar 15.

[11] Keita Kai, Masaaki Satake, Osamu Tokunaga.Gastric adenocarcinoma of fundic gland type with signet-ring cell carcinoma component: A case report and review of the literature. World J Gastroenterol. 2018 Jul 14;24(26):2915-2920.

[12] Venerito M, Link A, Rokkas T, Malfertheiner P.Review: Gastric cancer-Clinical aspects. Helicobacter. 2019 Sep;24 Suppl 1:e12643.

[13] McDonald SA, Greaves LC, Gutierrez-Gonzalez L, Rodriguez-Justo M, Deheragoda M, Leedham SJ, Taylor RW, Lee CY, Preston SL, Lovell M, Hunt T, Elia G, Oukrif D, Harrison R, Novelli MR, Mitchell I, Stoker DL, Turnbull DM, Jankowski JA, Wright NA. Mechanisms of field cancerization in the human stomach: the expansion and spread of mutated gastric stem cells. Gastroenterology. 2008 Feb;134(2):500-10.

[14] Takayasu V, Goto EH, Casagrande MZ, Miranda PGA, Diniz GBF, Monteiro MF, Felipe-Silva A.Bicytopenia and leukoerythroblastosis: a rare initial presentation of signet ring cell gastric adenocarcinoma. Autops Case Rep. 2017 Jun 30;7(2):55-60.

[15] Bostjan Humar, Ryuji Fukuzawa, Vanessa Blair, Anita Dunbier, Helen More, Amanda Charlton, Han Kwang Yang, Woo Ho Kim, Anthony E Reeve, lain Martin, Parry Guilford.Destabilized adhesion in the gastric proliferative zone and c-Src kinase activation mark the development of early diffuse gastric cancer. Cancer Res. 2007 Mar 15;67(6):2480-9.

[16] Sherif M Karam, Timothy Straiton, Wail M Hassan, Charles Philippe Leblond.Defining epithelial cell progenitors in the human oxyntic mucosa. Stem Cells. 2003;21(3):322-36.

[17] Sherif M Karam, Timothy Straiton, Wail M Hassan, Charles Philippe Leblond.Defining epithelial cell progenitors in the human oxyntic mucosa. Stem Cells. 2003;21(3):322-36.

[18] Kim KM, Park CK. Pathology of endoscopic submucosal dissection; how do we interpret?. Korean J Gastroenterol. 2010 Oct;56(4):214-9.

[19] Wang YK, Pathology of gastric tumors,Gao CF, chief editor of Wang YK.

Digestive system oncology. Beijing: People's military medical press,2012,296-404.

[20] Phalanusitthepha C, Grimes KL, Ikeda H, Sato H, Sato C, Hokierti C, Inoue H.Endoscopic features of early-stage signet-ring-cell carcinoma of the stomach. World J Gastrointest Endosc. 2015 Jun 25;7(7):741-6.

[21] Pokala SK, Zhang C, Chen Z, Gamboa AM, Cristofaro SL, Keilin SA, Cai Q, Willingham FF.Incidence, Survival, and Predictors of Lymph Node Involvement in Early-Stage Gastric Signet Ring Cell Carcinoma in the US. J Gastrointest Surg. 2018 Apr;22(4):569-577. 
[22] Yang-Kun Wang, Zhong Chen, Tian Yun, Cong-Yang Li, Bo Jiang, Xue-Xia Lv, Guang-Hui Chu, Su-Nan Wang,Hui Yan, Lei-Feng Shi . human epidermal growth factor receptor 2 expression inmixed gastric carcinoma. World Journal of Gastroenterology,2015, 21(15) $ه 4680-4687$.

[23] Yamagiwa H, Yoshimura H, Onishi T. A clinicopathological study of signet-ring cell carcinomas of the stomach. Gan No Rinsho. 1990 Jan;36(1):45-9.

[24] Tourani M, Habibzadeh M, Karkhah A, Shokri-Shirvani J, Barari L, Nouri HR.Association of TNF-a but not IL-1 $\beta$ levels with the presence of Helicobacter pylori infection increased the risk of peptic ulcer development. Cytokine. 2018 Oct;110:232-236.

[25] Youn Nam S, Park BJ, Nam JH, Ryu KH, Kook MC, Kim J, Lee WK. Association of current Helicobacter pylori infection and metabolic factors with gastric cancer in 35,519 subjects: A cross-sectional study. United European Gastroenterol J. 2019 Mar;7(2):287-296. 35,519

[26] El Khadir M, Alaoui Boukhris S, Benajah DA, Ibrahimi SA, Chbani L, Bouguenouch L, El Rhazi K, El Abkari M, Nejjari C, Mahmoud M, Bennani B.Helicobacter pylori CagA EPIYA-C motifs and gastric diseases in Moroccan patients.Infect Genet Evol. 2018 Dec;66:120-129.

[27] Yang-kun Wang.Gastric tumor pathology[M]//Chun-fang Gao,Yang-kun Wang.Digestive oncology.Beijing:People's Military Medical Publishing House, 2012,296-404.

[28] Marques MS, Melo J, Cavadas B, Mendes N, Pereira L, Carneiro F, Figueiredo C, Leite M.Afadin Downregulation by Helicobacter pylori Induces Epithelial to Mesenchymal Transition in Gastric Cells.Front Microbiol. 2018 Nov 9;9:2712.

[29] Sgambato D, Miranda A, Romano L, Romano M.Gut microbiota and gastric disease.Minerva Gastroenterol Dietol. 2017 Dec;63(4):345-354.

[30] Suzuki H, Mori H.World trends for H. pylori eradication therapy and gastric cancer prevention strategy by H. pylori test-and-treat. J Gastroenterol. 2018 Mar;53(3):354-361.

[31] Wang YK,Non neoplastic diseases of the stomach [M]//Gao CF, Wang YK. Diagnosis and treatment of digestive system diseases. Beijing: People's military medical press,2015囚581-675.

[32] Dhakal M, Dhakal OP, Bhandari D, Gupta A. Gastric xanthelasma: an unusual endoscopic finding. BMJ Case Rep. 2013 Oct 28;2013:bcr2013201017.

[33] Neeland IJ, Ross R, Després JP, Matsuzawa Y, Yamashita S, Shai I, Seidell J, Magni P, Santos RD, Arsenault B, Cuevas A, Hu FB, Griffin B, Zambon A, Barter P, Fruchart JC, Eckel RH; International Atherosclerosis Society; International Chair on Cardiometabolic Risk Working Group on Visceral Obesity. Visceral and ectopic fat, atherosclerosis, and cardiometabolic disease: a position statement. Lancet Diabetes Endocrinol. 2019 Sep;7(9):715-725.

[34] Hoffmann W.Self-renewal of the gastric epithelium from stem and progenitor cells. Front Biosci (Schol Ed). 2013 Jan 1;5:720-31.

\section{Figures}

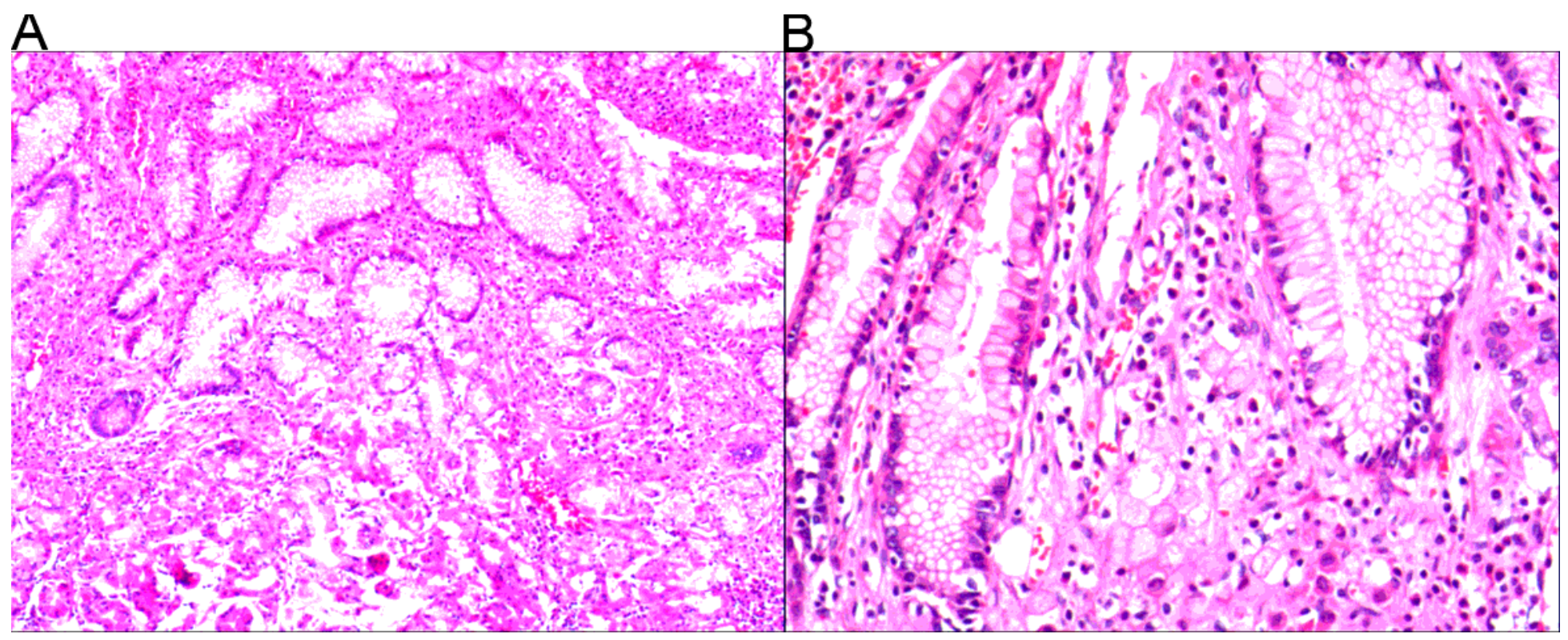

Figure 1

Signet ring cell carcinoma of gastric fovea. A.Mucinous glands increased in the upper part of the neck, and H \& E staining for X100. B. The glands were slightly dilated and stained with H \& E for X200. 


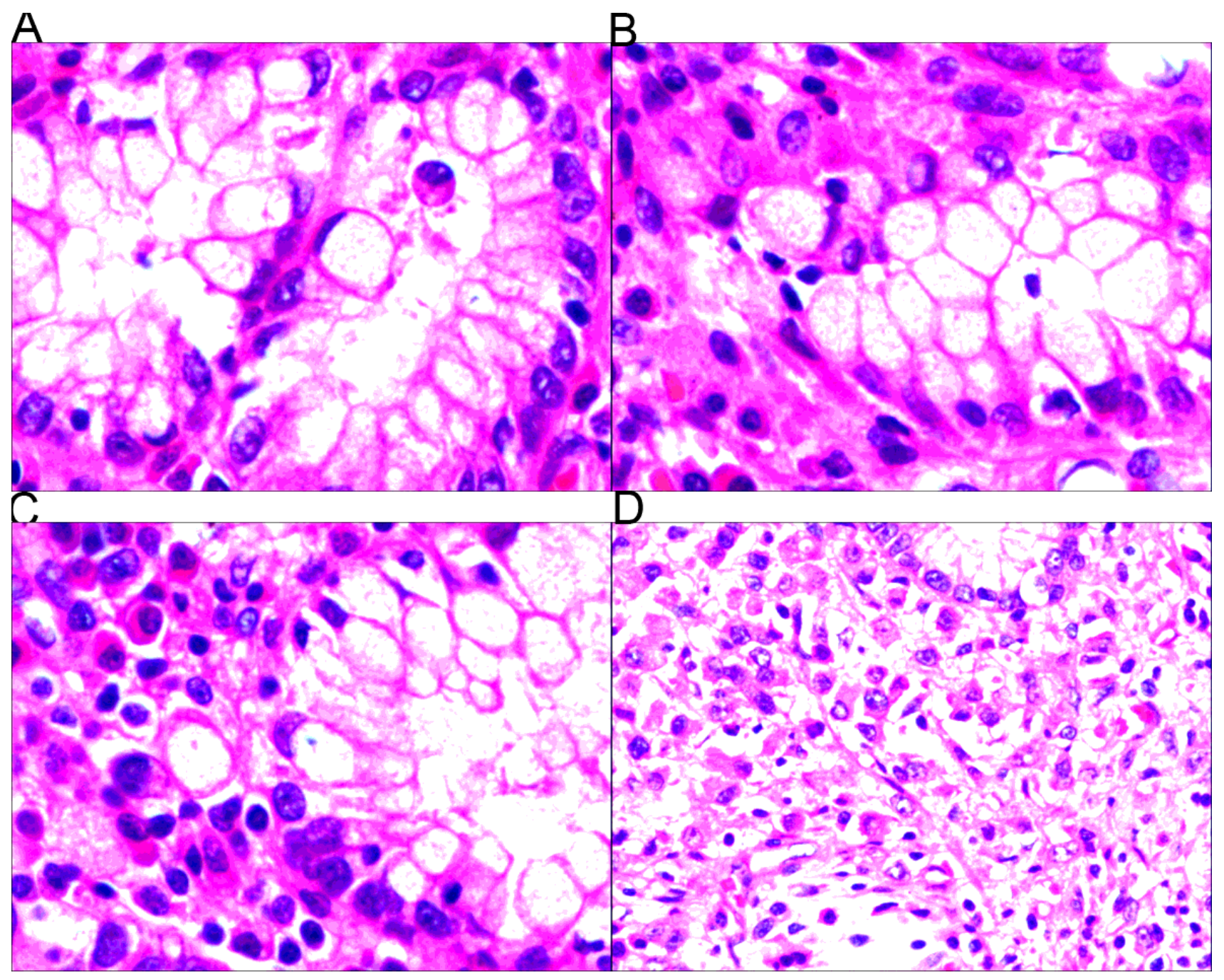

Figure 2

signet ring cell carcinoma of gastric fovea, signet ring cell like atypia. A. In the area between the cells of the cervical mucinous gland, the cells were round and enlarged in volume. The diameter of the cells was 1-2 times of that of the surrounding columnar epithelium, and the nucleus was crescent shaped. $\mathrm{H} \& \mathrm{E}$ staining X400. B. Signet ring cell like atypia cells were transplanted into the gland and stained with H \& E for X400. C. Signet ring cell like atypia cells were located in the stroma and stained with $\mathrm{H} \& \mathrm{E}$ for X400. D. There were a large number of immature signet ring cells in the proliferative zone, but no signet ring cell like heterotypic cells, X200. 
A

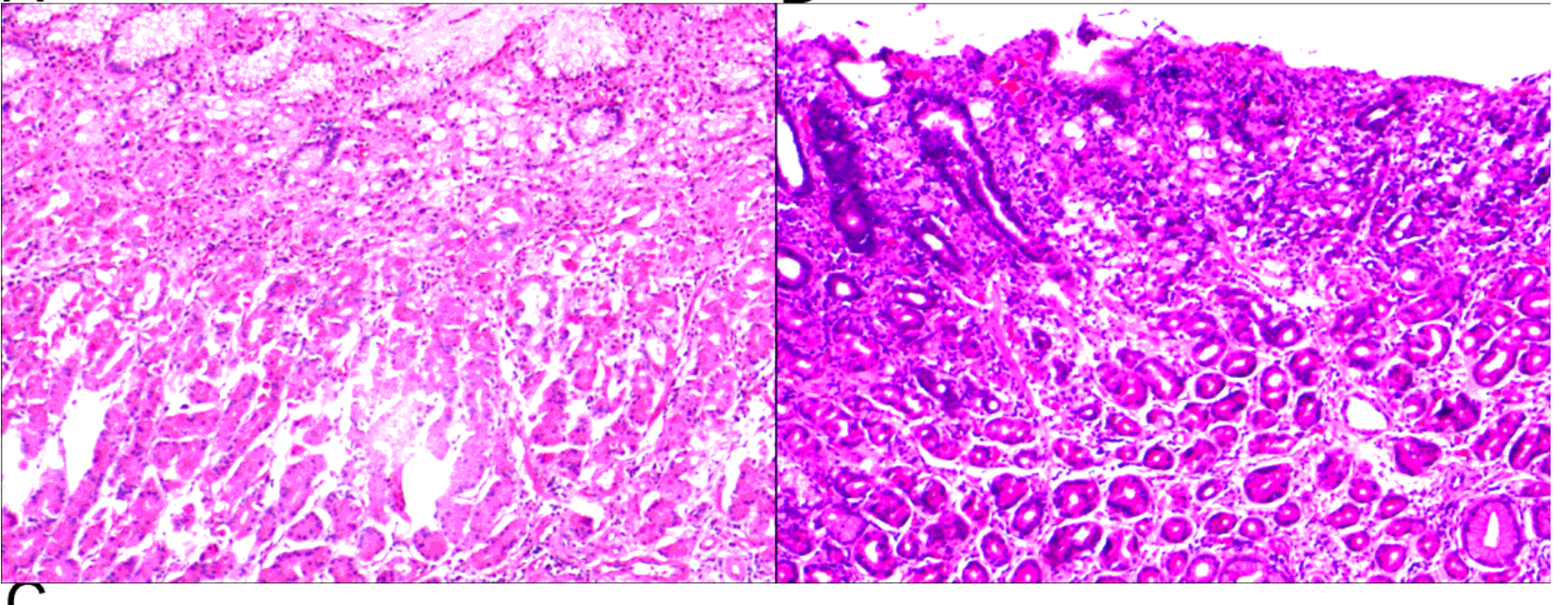

C

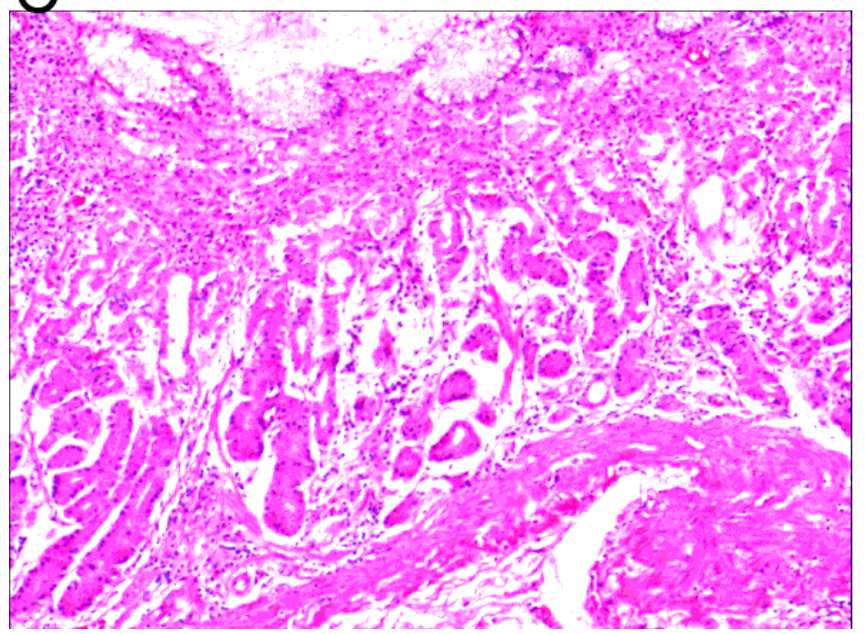

Figure 3

histological morphology of signet ring cell carcinoma of gastric fovea. A. The cancer cells were located in the proliferative zone of the fundus of gastric fovea and the neck of gastric gland. The 1 / 3 area of the gastric fundus mucosa opening side showed transverse expansion, $\mathrm{H} \&$ EX40; B. Gastric mucosal erosion or small ulcer formed on the surface of gastric mucosa; $\mathrm{H} \& \mathrm{EX}$ X0. C. Because signet ring cell carcinoma originated from the neck of the gland, the cancer cells prevented the normal differentiation of gastric fundus gland / pylorus gland. At the same time, cancer cells could cause atrophy of gastric fundus gland / pylorus gland and form local mucosa thinning, H \& E X40.

A

B

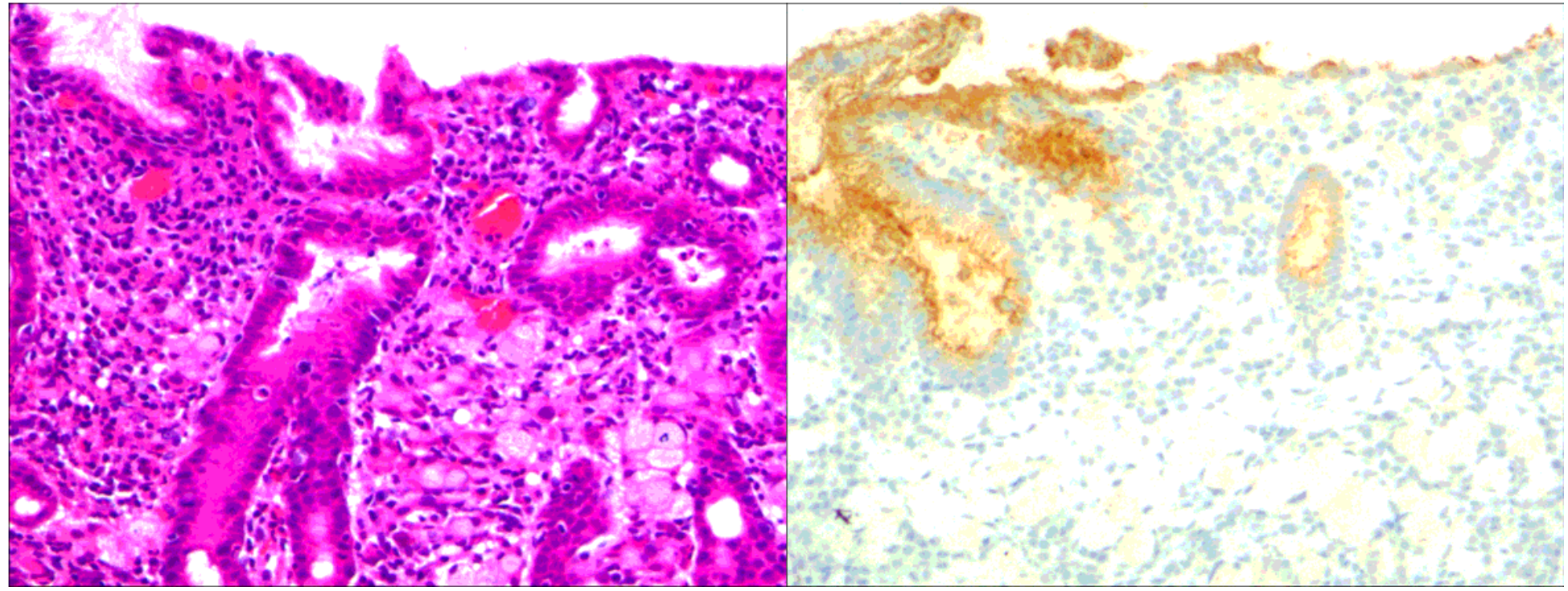




\section{Figure 4}

Pit epithelial signet ring cell carcinoma. A. The expression of he $\mathrm{x} 200$ in gastric fovea epithelial signet ring cell carcinoma with Helicobacter pylori infection and infiltration of inflammatory cells such as interstitial lymphocytes, plasma cells and neutrophils; B. Helicobacter pylori showed Brown expression, en vision method, HP X200.

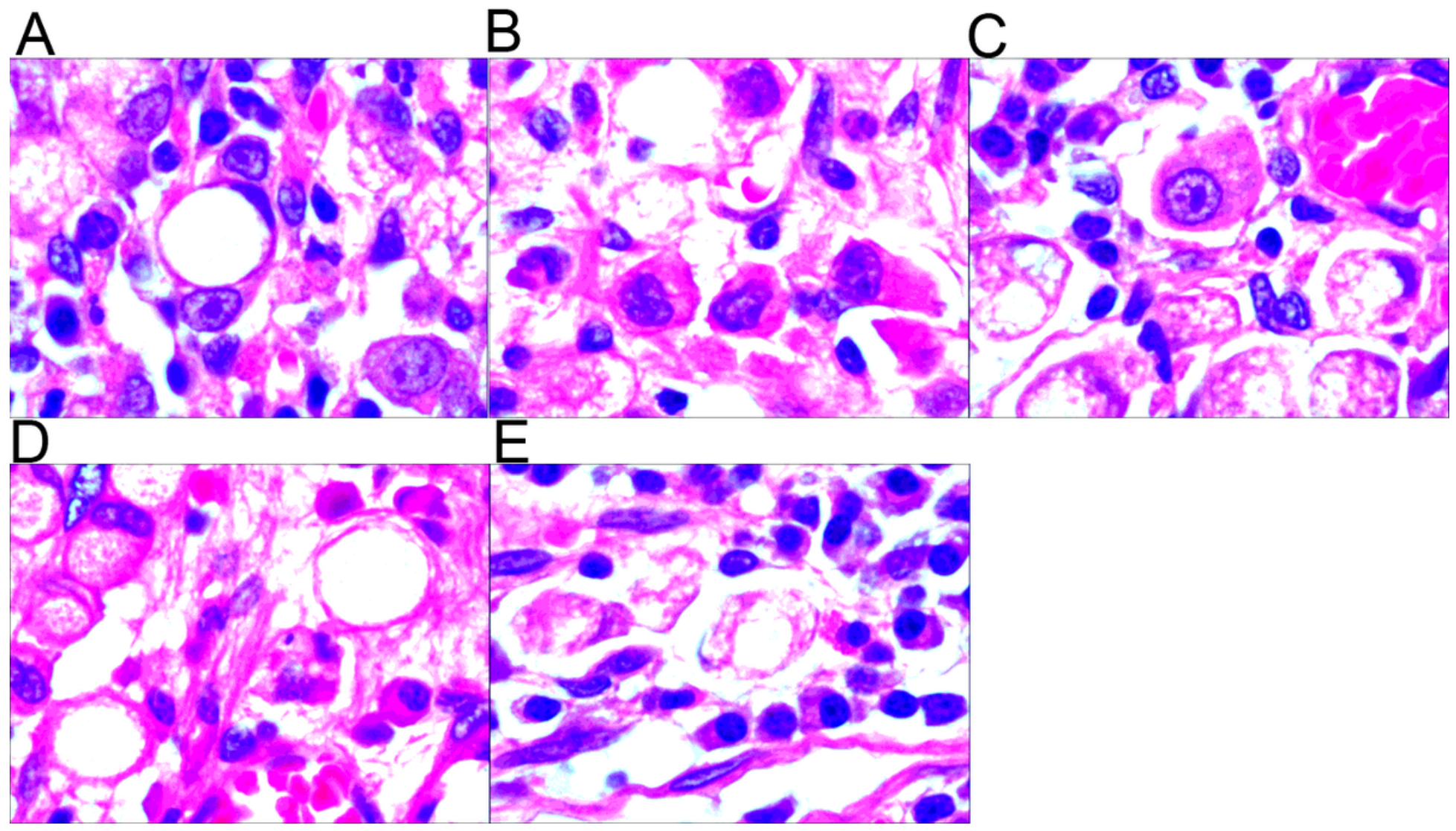

Figure 5

differentiation process of five kinds of cells in gastric fovea epithelial signet ring cell carcinoma. A. Typical signet ring cell, classic signet ring cell, round cell, 15-30 $\mu \mathrm{m}$ in diameter, with reddish mucus in the cytoplasm; nucleus deviation, signet ring shape or crescent shaped nucleus, hex600; B. The results showed that the immature signet ring cells were round or irregular in shape and strongly eosinophilic in cytoplasm; the nucleus was irregular round or ovoid, biased, with a ratio of 1:1 to 3; the chromatin of nucleus was bichromatic, hex600; the nucleus of signet ring ring cell was round or irregular in shape, and the cytoplasm was strongly eosinophilic; $\mathrm{C}$. High proliferative signet ring cells were round or oval with uniform cytoplasm and stained with bicolor mucus. The nuclei were large, with prominent nucleoli, and the nuclei were biased; D. The type of signet ring cells was caused by the relationship between the sections during the preparation. It still kept the outline of the cytoplasm. The cytoplasm was stained with light red mucus, hex600; $\mathrm{E}$. The cell volume of degenerative signet ring cells increased from 20 to $40 \mu \mathrm{m}$ to $50 \mu \mathrm{m}$, with capsule or incomplete capsule, small and light stained nucleus, dark or no nucleus, hex600. 


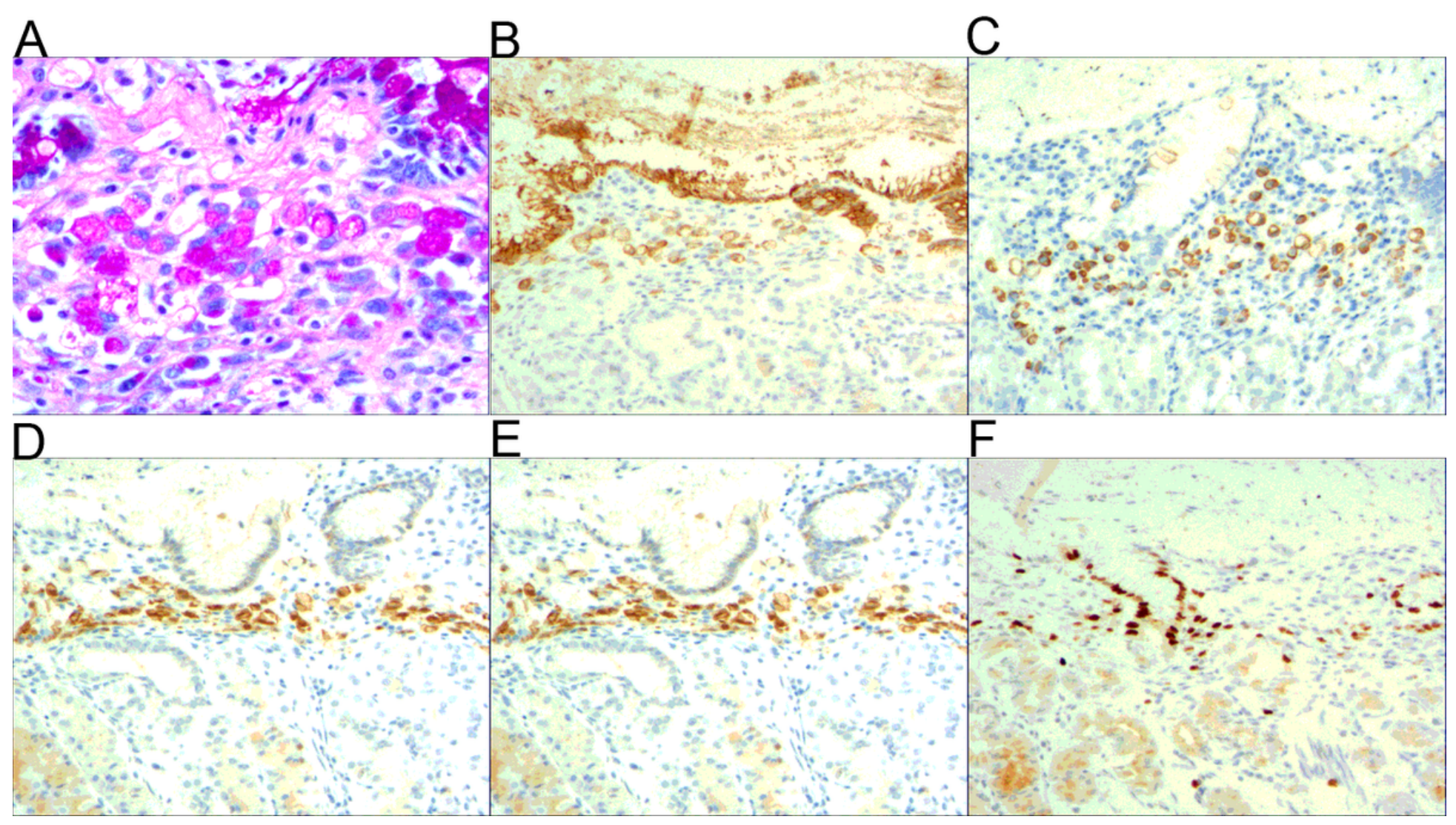

Figure 6

Pit epithelial signet ring cell carcinoma. A. Signet ring cell carcinoma was purplish red with special staining of PAS X200; B. MUC5AC signet ring cell carcinoma positive expression, en vision method, HP X200. C. The expression of CK20 signet ring cell carcinoma was positive; en vision method, HP X200. D. The results showed that villin signet ring cell carcinoma was positive; e. MUC2 signet ring cell carcinoma was positive; e. en vision method, HP X200. f. The number of Ki-67 positive cells was 44\%, en vision method, HP X200. 